\title{
Violence Against Women: A Reading of Amma
}

\section{Darko's Faceless}

\section{Maina Ouarodima, Ph.D}

\author{
Department of English, University of Zinder, Niger
}

\begin{abstract}
Despite the increasing worldwide interest for a society without discrimination, the space occupied by contemporary African women is still a domain that needs a close examination. Literature being the domain of visibility and audibility, especially in problematizing African women's space, several researchers have interrogated Amma Darko's Faceless from various angles, to point out the socio economic and political problems faced by women and or children (basically girl children); but, however, our reading of the novel presents alternative realities that are not yet evoked. That is, in Faceless, Amma Darko does not only voice the problems of African women, to strike women's awareness to break the yoke of silence, but, also and mainly, the novel is addressed to the leaders whose attitudes and conspiracy of silence have exposed women to various kind of violence. For Darko, the truth of the matter is that in a society where there is "the National Commission on Children, the Commission on Human Rights and Administrative Justice, FIDA, the Nation Council on Women and Development and the Attorney General and Minister of Justice" (Darko, 2013:182), security issue, in general, and women's security, in particular, should not be a matter of personal concern or even that of any non-governmental organizations such as MUTE. Within the framework of gender studies, our findings have revealed that not only women are marginalized but also and mainly that the marginalization is due to the loss of priorities by the government.
\end{abstract}

Keywords-Corruption, Faceless, Gender, Marginalization, Violence.

\section{INTRODUCTION}

Human civilization is made by and for both men and women (Ayayi, 2005:19). As a result, both men and women have their own rights and needs to live with modest admiration. What is more, many institutions over the world encourage citizen participation by seeking the representation and participation of everyone, irrespective of sex, in the conduct and management of their affairs (UDHR, 1948).Then, why men hold most of the important socioeconomic and political activities and, as well as, marginalize women and reduce them to silence? The question, certainly, serves as a catharsis for the following statistics:

Mineke observes that a recent UN study, about women's position in the world, shows that women carry out two-thirds of the world works, both within and outside the home, but they receive only ten percent of the world salary. Again, women possess less than a hundredth of the world wealth (Jones, 1987:35). According to the same study, in Africa, there are four times more illiterate women than men. In the schools, the higher the level of education, the less the proportion of girls (Jones, 1987:35).
Joyce A. Mangvwat (1999:6) brings into focus UNESCO statistics whereby the proportion of women illiterates is getting higher and higher: "in 1960, 58 percent of illiterates were women, by 1970 this percentage had risen to 60 percent and by 1985 the number of women illiterates had gone up to 133 million. Out of the total increase of 154 million illiterates, 86 percent were women."

Christine (1980:12) observes that: "Men monopolized higher education giving an excuse that women do not become chiefs, therefore why to educate them for long?" This is, probably, one of the reasons why, we have few female writers compared to male writers. For Zulu Sofola, the reason why few women write is that "...the women are more burdened with humdrum of daily life than men. And therefore it takes extra-effort on the part of the female to write..." (Henrietta, 1989:60).

What is more, even the political system that normally allows women the right to cast one's vote just as their husbands, fathers or brothers do, seems controversial to women. According to Dora (1991:12), when voting time comes, a woman "waits for directives from her husband if 
she is married or from her father or head of the family if she still lives at home to tell her which box to throw her vote in." As a result, the rhetorical question, which we are tempted to raise, is: how can one expect a free and fair election when more than $50 \%$ of the electorate, the women, do not know that they have a choice?

Although it is 'conventional wisdom' that societies in Africa severely limited women's political power, by often misinterpreting religious principles, Hadjia Bilikisu Yusuf has this to say: "No religion to the best of my knowledge forbids women from active participation in politics. Being a Muslim, I know Islam allows women to vote and be voted for. It provides for women's views to be heard on private and public affairs" (Dora, 1991:64, emphasis mine).

Though the above statistics better fit a sociological research, it is good to remind that even fictional narratives very often generate from real life experiences. That is, the portrait of many of the fictional heroines, in African women's works, is the portrait of African women trying to unload the double, often multiple yokes on their backs. Mary (1997:174) rightly says that: "It is generally accepted that African literature is largely biographical either at the personal or collective levels..." Furthermore, Mary (1997:204) has been specific in pointing out that, for African women writers, literature is an "imitation of African women's reality and inscription of their values..." Juliana (1997:6) puts a seal that "women are now writing about women and bringing not only their points of view but [mainly] lived experiences as women to their writings." Thus, the novel Faceless is no exception.

In fact, if we look at the position of women as described in the above statistics, there is a wide range of constraints and obstacles that impede women's progress and limit their abilities to occupy leadership positions whether in public or even in private sectors. Since the oppression of women constitutes a great barrier for the development of Africa, the aim of African women writers, in general, and that of Amma Darko's, in particular, is to utter a cri de Coeur for a new optimistic Africa, free from the yoke of discrimination and the proliferation of violence that mostly affect women. By women, in this research, we mean all individuals of female sex whatever the age. This is because, even those who are considered teenagers, in Faceless, perform almost all that adult women perform (Darko, 2013).The marginalization is brought to the surface in the next section through the reading of Amma Darko's Faceless. The section informs us of the 'ongoing' discriminatory practices, against women, which certainly serve as a catharsis for Darko to write or to bring to the front burner of public discourse issues that affect the physical and even the spiritual well-being of women.

\section{MARGINALIZATION OF WOMEN AS PORTRAYED IN FACELESS}

To begin with, women are marginalized almost everywhere. Evidently, the titles of fictional narratives produced by female writers across Africa (Double Yoke; Second Class Citizen; Women are Different; One is Enough; The Slave Girl; So Long A Letter; The Joys of Motherhood; The Stillborn, Faceless...) suffice to portray the moral tragedy of innocent individuals. Each title, according to Nnolim (2009:140), "reflects just one or more phase in the brutalized plight of women in the hands of the 'enemy' man." Juliana (1975:5) rationalizes that:

Whether she is elevated to the status of a goddess or reduced to the level of a prostitute, the designation is degrading, for he [man] does the naming. Whereas her experience as a woman is trivialized and distorted. Metaphorically, she is of the highest importance, practically she is nothing. She has no autonomy, no status as a character, for her person and her story are shaped to meet the requirements of his [man's] vision. One of these requirements is that she provides attractive packaging. She is thus constructed as beauty, eroticism, fecundity- the qualities the male Self values most in the female Other.

More than a mere representation, the above quotation, as well, illustrates the general position of women as seen by men. It is clear that whatever the position of a woman, she is made to please man. However, our concern and focus, in this section, is Amma Darko's Faceless. Thus, the society of Faceless, as described by Darko, is full of restrictions. A woman does not have space of her own or a position of her own. While, for instance, it is known that the happiness of a married couple lies on the contribution of each partner, woman's expectation for a better couple, where there is love and mutual understanding, often turns to be a disappointment as men tend not to offer a mere smile to their wives. Yet, to deprive a woman of a mere smile within a couple is nothing else than marginalizing a woman. In Faceless, a little boy reports that his "mother never had a smile as his father had 
never tempted to make her smile" (Darko, 2013:2).However, what is bad, the side effect of such attitude from a man or even better from a husband conditioned a woman or a wife to be cruel. The same little boy adds that: "I cannot help thinking that maybe she [his mother] never has a smile for me because the man she made me with, that is my father, probably also never had a smile for her" (Darko, 2013:2).

Darko points that even when it happens that both boys and girls find themselves on the street, the living condition of boys is far better compared to the living condition of girls, because girls are more exposed to dangers. For instance, on the street, Fofo was about to be abused by two boys, one of them known as Poison, the street gang. The cry uttered by Fofo proves her vulnerability. We learn through the narrator's comment that: "Fofo let out a cry and began to flail her hands and legs widely in the air. One huge muscular hand came down hard upon her mouth and suppressed the sounds from her throat. The other restrained her flailing hands and legs" (Darko, 2013:3-4). Later, Fofo, herself, reports to her friend Odarly that Poison tried to rape her: "The person I said [Poison] tried to rape me, that was him" (Darko, 2013:8).

What is more, the economic condition of married women seems to be even more vulnerable than the condition of the street girls. Fofo speaking of her mother, when her friend Odarley asks her what she is looking for upon visiting her mother, reacts: "Am I a dreamer? She and me who needs money more?"(Darko, 2013:8). The truth of the matter is that despite Fofo is a street girl, her married mother has more economic problems than she has. Fofo further laments the living condition of her mother within marriage and adds: “...I don't like coming to see you because I don't like what I feel when I come to see you..." (Darko, 2013:25). This “...what I feel when I come to see you..." uttered by Fofo is, further, made more explicit: "If he [Fofo's father] returned today you would let him in and probably get yourself pregnant by him again, won't you? Why? Mother, why? What life have you been able to give those of us you already have?" (Darko, 2013: 159).

Through another character, in the novel, Darko, aesthetically, supports Fofo's viewpoint. During a radio interview, with Sylv Po, a woman reacts: "I want to know if I can apply any existing law to legally prevent our parents from having any more children after the one presently carried is born" (Darko, 2013:182). That is, no child should be brought into the world without means of providing for him or her physically, financially, psychologically and even emotionally.
In fact, in faceless, the marginalization of women is a daybreak when it comes to the choice between a boy and a girl child. Though, the prayer on the lips of many African married couples is that God gives them children, they may have preference over a boy child or else a boy child is very special. Such attitude is even known to children. Ottu, the only son of Kabria out of the three she mothered, once says: "Mum, do you know that I cut short your problems by coming as a boy and earned you respect?" (Darko, 2013:13).

What is more, as the mother, herself, is surprised of her little child analysis; Ottu was able to report a similar case from another family: "You see [speaking to his mother], my friend's grandfather said that had my friend not come as a boy, she, being my friend's father's mother, would have insisted and ensured that my friend's mother continued to bear more and more children till she born a son" (Darko, 2013:13).

In addition to the above, when a married couple is not blessed with a child or children, the blame is on women as if procreation is not a result of a joint action between a man and a woman. A woman who is not fertile is most often divorced. In Faceless, Dina, the Boss of MUTE, experienced such pain: "Dina was a graduate of the University of Ghana. Her marriage to her campus boyfriend shortly after her graduation, ended in divorce after four turbulent years of childlessness" (Darko, 2013:38).

Also, though school is an important socio economic and political ladder, girl children do not have the opportunity to go to school. School is a reserve of men who grap the benefit. It is at the tender age that girls are involved in the street life. Though, thanks to education, men are able to work and earn salaries, one is tempted to question what the salary is worth as they, most often, spend their salaries on beers: "After work, Adade [kabria's husband] normally met with friends at a drinking spot to socialize over bottles of beer" (Darko, 2013:14, emphasis mine). The so-called socialization is celebrated while the kids are on the street at the mercy of all kind of dangers. That is certainly why, Darko creates a character such as Kabria.

Through Kabria, the writer does seem to tell women that even though they are married, marriage is not a profession and that men are not banks to rely on. Kabria once said to her husband, who asks her whether she receives salary from her work or not, that: "Don't get sarcastic with me" Kabria retorted. "If I had had the time to study further as you did, I would also have been reaping the benefits today in terms of a better salary. But I was busy making babies then" (Darko, 2013:15). The fact that women do not have salaries does not 
mean that they do not work. They work often harder than men do but their works are penniless. In Faceless, a report once alleged that the "African woman worked for an average of sixty-seven hours a week as opposed to fifty-five for the African men" (Darko, 2013:56). Darko is critical of such situation that debases women.

Since women do not go to school, they have little chance to do office works. Therefore, poverty greatly affects them. When, in Faceless, Kabria asks a blind woman the reason why the little girl of eight years old, guiding her, is not going to school, the blind woman responds: "If people like you won't give me money, how could I send her to school?" (Darko, 2013:37). In the novel, it is said that Fofo does not only know poverty but she even sees it. This is an indication that poverty is even personified. Poverty often drives women to the expense of reason and the situation involves them in prostitution, as a survival strategy: "They [the girls] had no idea at all about the extent of self-damage. Sex, to them, was just a convenient means of survival" (Darko, 2013:32).

What is more, they are not even able to conduct the sex business freely because they are often raped. They are raped by street gangs and often by relatives. Darko informs us that, for many girls, "rape was their first sexual experience" (Darko, 2013:32). For instance, at sixteen years old, Baby T. was raped both by her own uncle, Onko, and by her stepfather, Kpakpo. However, as poverty is a rule but not an exception, Onko bribes Maa Tsuru, Baby T.'s mother, to keep silence and threatened Baby T. not to tell anybody: "three times he did it, and left her bleeding on his bed. 'Better tell no one!' he warned" (Darko, 2013:139). Accordingly, Christine (1980:16) observes that "...majority of women assume 'silence is golden' because they lack the confidence or education to deal with male dominance."

Worst of all is that often men tend to marginalize women without reasonable evidence. Rightly, a saying goes on that "If one does not need one's dog, one accuses it of rabies and kills it". In the context of a relationship between a woman and a man, the latter often takes even a dream for granted. For instance, during a radio interview with Sylv Po, Ms. Kamame says:

We met a woman whose husband had left her, after several years of marriage, with six children. He claimed he had a vision from God in which it was revealed to him that his wife was an adultress, that he had fathered none of the six children. One week later, he announced another vision. This time, he said God had revealed the new woman he should marry to him. The new woman turned out to be a young member whom everyone knew he had been eying since she joined the church. The man was an elder of the church. No one challenged him. How was the woman to afford paternity tests to debunk his absurd allegations? (Darko, 2013:110).

The marginalization of women has reached its summit because even beating a pregnant woman is worth celebrating, at least for some men. For instance, MaaTsuru was pregnant of Kwei for the third time. However, as Kwei was not happy of the pregnancy, he attempts to make her abort by giving a 'sound' beating. Not only that, Kwei returns to friends and tells them, as we learn from the narrator's comment, that with " immediate effect, they had better start calling him Dr. Kwei, because he had singlehandedly and very cost effectively terminated an unwanted pregnancy" (Darko, 2013:124). Moreover, when 'Dr. Kwei' learned that MaaTsuru was safe and as well as her baby, his reaction was: "How had MaaTsuru and the baby inside her survived his pounding?" (Darko, 2013:124). In the end, as opposed to the naming tradition, the baby was never honored with a Kwei's family name at birth: "she went first by the name 'Tsuru's baby'; which evolved to 'Baby Tsuru'; and then, to 'Baby T." (Darko, 2013:125).

From the recollection of the above evidences, from the novel, the society is very hypocritical. It is so to the extent that even when the campaign against AIDS was launched, the sensitizers tend to focus on the use of condom rather than abstinence. In the novel: "Sylv Po's female studio guest was on and complaining about the AIDS prevention campaign not driving home the message of abstinence and faithfulness with the same intensity as the use of condoms" (Darko, 2013:32). Yet, such hypocritical attitude would not help develop a nation. Umeh (1998:168) supports that "A society which sets double moral standards for its adult population based on sex and gender is setting up the society for perpetual condonement of discrimination against the weak."

In the novel under analysis, Obea, one of Kabria's daughter, rightly recalls her social studies teacher who once quoted John F. Kennedy, the former president of the United States of America, saying that: "The future promise of any nation can be directly measured by the present prospects of 
its youth [both men and women]" (Darko, 2013:75). As the marginalization of women is made explicit through the reading of Amma Darko's Faceless, then who does the author, aesthetically, hold responsible for?

\section{PORTRAYAL OF A FAILED GOVERNMENT}

As human beings live in a society, there are, certainly, relations and interrelations between people who live together. Naturally, as people come from different socio cultural backgrounds with different material conditions and speaking different languages; it follows that their worldviews, thoughts, visions, feelings, likes and dislikes are different. Also, knowing that one cannot, normally, do whatever pleases him or her, no matter how rich or powerful he or she is, then the power belongs to the government, an organized institution, to ensure the basic needs of the population such as education, health care, social justice, security... irrespective of sex and as well as develop strategies to ensure a better living condition to its population. This is known to MaaTsuru who once says: “...it is the government who had the power to make people do or stop doing certain things [things refer to everything that needs mutual understanding]" (Darko, 2013:79). The above-mentioned basic needs are necessary for a society to prosper so that its members live in harmony with one another. However, are such expectations fulfilled by the government? Especially when we know that both men and women have their own rights and needs to live with modest admiration?

The answer to the above question is certainly no. This is because despite the establishment of institutions such as the "National Commission on Children, the Commission on Human Rights and Administrative Justice, FIDA, the Nation Council on Women and Development and the Attorney General and Minister of Justice" (Darko, 2013:182), women are still marginalized due to the dysfunction of the above mentioned institutions. The dysfunction is known to Bell (2015:43) when she states that: "women are the group most victimized by sexist oppression. As with other forms of group oppression, sexism is perpetuated by institutional and social structures..." For instance, the issue of security has become a matter of personal concern to the extent that women tell their daughters to go away, on the street, just to look for a secured place where there is no man to hunt them. At home as well as on the street, if ever they are abused, there is nowhere to complain about the odds. Not even the ministry of justice would attempt to protect the victims through the security forces such as the police or the court judges. This is because, even the police agents do not do their jobs.

In fact, when Kabria, a member of MUTE, went to the police station to investigate about a girl's dead body, found behind a kiosk, and asked the inspector if anything was done; the latter retorted: "Bodies are found at all kind of places at all sorts of times"(Darko, 2013:81). What is more, even if they want to do their jobs, they are in short of materials. When Kabria insisted on seeking information about a girl's dead body, the inspector keeps telling her the problems that the police station, itself, faces such as no cars, no materials...(Darko, 2013).Seemingly, fighting for women victims seems not to be the priority of the government.

The lack of interest on women's preoccupation is, certainly, what pushes Dina to establish a non-governmental organization called MUTE. It is good to point out that MUTE is not an acronym but it translates silence. All the members of MUTE are women and their concerns are women. This is because, if one takes a close look at the nature of the oppression, sex does determine the situation of women in a very fundamental way. For instance, men in the novel are dominant and assume the position of influence and authority not on any other 'merit' than being male.

Members of MUTE are aware that it is a problem to be a female, in the society of Faceless. It was MUTE that conducts all the investigations about a girl's dead body until they get evidence that Poison was the murderer of the girl. However, security issue, in general, and women's security, in particular, should not be a matter of personal concern or even that of any non-governmental organizations such as MUTE but normally the concern of the government. Darko, in Faceless, is very critical of such a loss of priorities by the government.

What is more, even education, which is considered as one of the basic needs that any government should provide to its population, is not guaranteed. In other words, it is the responsibility of the government to provide free primary school to children, in general, and to girl children, in particular, but; unfortunately, this happens not to be the case. In Faceless, for instance, Fofo was registered at school and performed up to class two but later left because of her parents' inability to provide the basic needs: "but I [Fofo] went only up to class two. There was no money. Mother couldn't afford the uniforms and the exercise books" (Darko, 2013:100). Also, note that Fofo's father left home even before Fofo was born. It was poverty, as well, that pushed Baby T. to the street after class two. 
In the society of Faceless, corruption or materialism has reached its summit to the extent that when Aggie and Vickie were sent to the mortuary, by MUTE, to investigate on the dead body, a male nurse wonders how could they come all the way just to investigate a street girl dead body? Moreover, the male nurse adds: "Has she [the dead girl] turned out to be a relation of the president?" (Darko, 2013:149). The male nurse has later made his wonder more explicit when he says: "Honestly, whoever this dead street girl is, must be very lucky to have two fine women like you come here to find out what killed her. God knows how many bodies are cut up each day the causes whose of death show clear signs of murder but which end up gathering dust because no one was interested" (Darko, 2013:149). Fofo, as well, knows the hypocritical side of the society when she says that: “...learning to trust and have faith...was like a crawling child learning to walk" (Darko, 2013; 71). Didacticism in this case is that there is no attention given to the concern of the poor who are dominantly women.

More than once, Darko points out the irresponsibility of the government in handling with certain socio cultural problems such as begging. Upon mentioning the causes of 'streetism, during a radio interview with Sylv Po, Ms. Kamame points out poverty as a real cause of streetism and as well as "the incidence of absentee fathers, ignorance, distorted beliefs and perceptions, and most depressing of all, the instances of sheer irresponsibility and misplaced priorities" (Darko, 2013:108). For Fofo, begging is a route to streetism. She says: "I didn't just get up one day to live on the streets. It started with the begging. I was going out to beg on the streets, but I always returned home to mother in the evening" (Darko, 2013:100, emphasis mine).Darko points out that, for a serious government, a girl of seventeen years old is supposed to be at school rather than the market place or on the streets to beg. In other words, Darko does seem to say that as a little fire can become bigger, a little problem can also become tremendous if no immediate solution is taken.

\section{DARKO'S AESTHETICS MESSAGE FOR A POSITIVE CHANGE OF MENTALITY}

The novel Faceless opens with "she [a woman]" and closes with "life". The opening and the closing words are full of meaning. For Darko, a woman has a right to live her life meaningfully. Not all the socio economic and cultural position of women that she describes, in her novel, are related to fate but to the system of governance. That is men's inability or irresponsibility to cope, objectively, with the societal problems. The fact that her main character Baby T., around whom all the story of the novel goes on, is nameless, Darko, aesthetically, wants to say that it could be any other woman in the society. In other words, she does not want her readers or society, at large, to consider the story of Faceless as a story of a single individual. The testimony given by a male nurse is enough if ever evidence is needed to express the moral tragedy of innocent individuals: "God knows how many bodies are cut up each day the causes whose of death show clear signs of murder but which end up gathering dust because no one was interested" (Darko, 2013:149). Therefore, Darko's message is that enough is enough.

Through the creation of a non-governmental organization (MUTE) by a woman to focus on women issues, Darko has used her aesthetics to inform that women are marginalized, by bringing to surface the issue of security or women's security, which have become a matter of women's concern rather than the concern of the government. The didacticism in the message is that Darko is critical of the abandon of one of the most fundamental social needs, security. Rather, she informs, as well, that women must, like Diana who creates MUTE, map out survival strategies and succeed despite the crippling and stunting circumstances that define their existence in a culture unfavorable to women.

In fact, the problem of women, in the context of situation, knows no limit. At home, they are raped by relatives and very often by close relatives, who normally should provide them maximum security. On the street, not only the money they earn is not safe but also and mainly there too, they are raped by street gangs and forced to keep silence together with their mothers. What is more, there is nowhere to complain in case of abuse and if ever one does, none dare intervene. Darko's message is that how, in such a social condition, a woman would be able to study, to develop commercial strategies, achieve her talents and yet feel at ease? Darko calls on both men and women to consider that development is a result of a joint action. In as much as women are marginalized, the development of the society is dubious. Ama Atta Aidoo, the Ghanaian woman writer, seemingly conveys Darko's preoccupations when she says: “...it is not possible to advocate independence [development] for our continent without also believing that African women must have the best that environment can offer" (Umeh, 1998:304-305).

Overall, Darko's didacticism is that a violence can produce only violence. What is more, even when it happens that a man is ill-treated by a male relative, the man victim retaliates his sorrow on women who are the most vulnerable. For instance, even Poison, the street leader, is said to be a 
good man before he was threatened by his stepfather: "Poison ran away from home at the age of eight to hit the streets...he was an extremely shy boy, very soft spoken and covered from head to toe in scars gained from several years of lashes with a man's leather belt at the stepfather's hand" (Darko, 2013: 169). However, the core of the matter is that Poison retaliates to innocent women on the streets. In the novel, during a radio interview with Sylv Po, Ms. Kamame does seem to convey Darko's message that the government should deal with the issue appropriately and bring violence to its end. Otherwise: "Then you and I who thought it was their problem alone wake up one day to the rude realization that we have no choice but to share this same one society with them" (Darko, 2013:112).

\section{CONCLUSION}

A saying goes on that "If lions do not have their own historians, the story of the hunt will always keep glorifying the hunters" Amma Darko has certainly the saying in mind and then she works adequately to prove wrong all those who argue that the African women do not need liberation. Since modern academia describes human societies in relational terms, all women bear certain difficulties in relation to men. The research has proved that patriarchy, tradition, neocolonialism, gender imperialism, failed leadership, all combined to act against the African women's self-assertion. That is, certainly, why African women's texts have been concerned, explicitly or implicitly, with change.

Darko informs her readers and society, at large, that the African women's conceptualization of freedom is not based on the erosion of her feminine attributes and outlook but in her 'ability' to go to school, to work, to voice her opinions (her likes and dislikes). For such basic needs to be effective, Darko utters a wake- up call to the government, which has a tremendous role to play in it. The government should not lose its priorities and become deaf to the cries of the victims (women). As a result, both men and women should shoulder responsibilities and work jointly for the benefit of a society without dis-cri-mi-na-tion.

\section{REFERENCES}

[1] Ayayi, S. A. (2005). African Culture and Civilization. Nigeria: Atlantis Books.

[2] Bell. H. (2015). Feminist Theory: From margin to the center. New York: Routledge.

[3] Darko, A. (2013). Faceless. Accra: Sub-Saharan Publishers.
[4] Christine, O. (1980). African Women: Their struggle for Economic Independence. London: Hutchinson \& Co. Publishers Ltd.

[5] Dora, O. C. (1991). Nigerian Women and the Challenges of Our Time. Lagos: Malthouse Press Limited.

[6] Henrietta, O. (1989). Nigerian Female Writers: a Critical Perspective. Lagos: Malthouse Press Limited.

[7] Jones, El. D. Eustace, P. \& Marjori, J. (1987). Women in African Literature Today $N^{\circ} 15$. London: James Curvey.

[8] Juliana, M. (1997). Gender in African Women's Writing: Identity, Sexuality, and Difference. Indianapolis: Indiana University Press.

[9] Mangvwat, A. J. (1999). Gender and Access to Education in Nigeria. Nigeria: Arrowhead Publications.

[10] Mary, E. M. (1997). Womanism and African Consciousness. Trenton: Africa World Press, Inc.

[11] Nnolim, E. C. (2009). Issues in African Literature. Nigeria: Malijoe Soft Print.

[12] Umeh, M. (1998). Emerging Perspectives on Flora Nwapa: Critical and Theoretical Essays. Trenton, NJ: Africa World Press.

[13] Universal Declaration of Human Rights: Resolution $N^{o} 217 A$. Paris: United Nations, December $10^{\text {th }}, 1948$ 